\title{
An Empirical Examination of the Influence of Information and Source Characteristics on Consumers' Adoption of Online Reviews
}

\author{
T Sai Vijay \\ Indian Institute of Management Raipur \\ tsaivijay@gmail.com \\ Sanjeev Prashar \\ Indian Institute of Management Raipur \\ dr.sanjeev.prashar@gmail.com \\ Chandan Parsad \\ Indian Institute of Management Raipur \\ chandanparsad@gmail.com \\ Mukesh Kumar \\ Indian Institute of Management Raipur \\ mukeshjnu@gmail.com
}

\begin{abstract}
The growth of online commerce has given consumers a number of convenient options to shop from. This has led to the proliferation of e-commerce players that offer variety of products and services with customer-centric terms and conditions. However, absence of avenues to test the product(s) before buying, shoppers perceive inherent risk associated with online buying, especially related to products' quality and features, terms and conditions of sales, etc. To overcome this pre-purchase dissonance and compensate for the lack of previous experience, they look for reliable information and guidance. Hence, to make decisions, e-buyers rely on the reviews provided by other shoppers. Therefore, it becomes imperative for e-retailers to determine antecedent factors that influence the adoption of online reviews. Using heuristicsystematic model, this study has identified the relative significance of information credibility, argument quality, quantity sufficiency and source credibility in influencing the adoption of reviews available online. It was observed that the two categories of influencers impact the reviews' adoption albeit through the two mediators - perceived usefulness and perceived value of reviews. Theoretical and practical implications have also been highlighted.
\end{abstract}

Keywords: Online reviews, Source credibility, Information credibility, Quantity sufficiency, Argument quality, Heuristic-systematic model

Citation: Vijay, T. S., Prashar, S., Parsad, C. and Kumar, M. (2017). "An Empirical Examination of the Influence of Information and Source Characteristics on Consumers' Adoption of Online Reviews," Pacific Asia Journal of the Association for Information Systems, 9(1), pp. 75-94. 


\section{Introduction}

The advent of information communication technology (ICT) and digital media have altered the information-related behavior of consumers. To fulfil their information needs, consumers' dependence on online word-ofmouth (eWOM) has significantly increased. The online customer reviews encompass valuable evidence and data about varied products and services. These reviews play a pertinent role in disseminating information, enabling trust, and encouraging shopping. Besides existing and prospective buyers, online retailers also gather valuable information on a large scale at a minimal cost from this new resource. Since the online retail web portal with greater reviews and higher ratings attracts more consumers, e-retailers are asking their customers to share their assessment of the products/ services purchased, and the overall experience they had with the web portal (Schmallegger and Carson, 2008). This online word-of-mouth has also been observed to affect shoppers' offline decisions (King et al., 2014; Xie et al., 2016). Owing to the shift of consumers' role from passive to active, these reviews, being the new trends in online interactive communication, require complex marketing skills (King et al., 2014).

On the basis of a comprehensive survey, PricewaterhouseCoopers reported that forty-five percent of the surveyed sample read reviews, comments and feedback that influenced their online shopping behavior. While thirty-six percent populace in developed markets used online feedback, emerging markets reported it to be much higher at fifty-six percent. The country-wise analysis revealed greater inconsistencies. In Denmark, just twenty-two per cent of survey respondents were effected by reviews, comments, and feedback. On the other hand, the developing economies, China, India and Malaysia recorded the figures at sixty-three, sixty-six and sixty-nine percent respectively (PwC, 2016).
Deciphering the underlying factors and process in the information adoption of reviews could help e-retailers better promote their brand on the internet. The extant literature on online reviews pertains to developed markets like (e.g. Filieri and McLeay, 2014; Elwalda et al., 2016; Park and Lee, 2009; Xu and Yao, 2015; Zhang et al., 2014; Zhou and Duan, 2016). The findings of these studies, however cannot be generalized across the markets as sociocultural variances can impact the way online shoppers respond to the reviews available on different websites (Xu and Yao, 2015). As far as the authors know, no study in the existing literature has examined the online reviews' adoption behavior of Indian shoppers. This presents an ardent need for undertaking an empirical study to determine various antecedent factors influencing online reviews adoption in an Indian setting.

Also, most of the existing studies have applied Elaboration Likelihood Model (Cheung and Thadani, 2012), while very few research studies have used HeuristicSystematic Model (Zhang et al., 2014). Because of its ability to elucidate extensive information processing activities (Chaiken and Maheswaran, 1994) and extend more theoretical implications (Zhang and Watts, 2008), the present study has employed the HSM. Contrary to the earlier studies that have used few antecedents, the present study has used four predictors namely information credibility and argument quality (systematic factors) and source credibility and quantity sufficiency (heuristic factors). It has been posited in HS model that these predictor variables can have concurrent effect.

The present paper purports to investigate the relationship between predictor variables - information characteristics and source credibility, and adoption of online review. The study also determines the relative role of various antecedent factors in influencing the adoption of online reviews. Besides examining the mediating role of reviews' perceived usefulness and value, it also identifies the comparative effect of these 
two mediators. It also contributes to the online marketing literature by proposing a conceptual model and empirically validating the relationships among the variables in the Indian context. The paper opens with the review of literature and formulation of related hypotheses. The conceptual framework for the study has been presented thereafter. The following section contains the testing of the model with responses from 320 online shoppers of Amazon.in. The paper closes with deliberations on the findings, implications, limitations and opportunities for future studies.

\section{Literature Review and Hypotheses Formulation}

\begin{abstract}
Online reviews has been elucidated as "peer-generated product evaluation(s) posted on company or third-party websites." (Mudambi and Schuff, 2010, p. 186). Written assessments of the products on the web portals (Stauss, 1997), reviews are a type of e-word-of-mouth (eWOM) communication by online shoppers, spreading and interacting casually and noncommercially. This interaction helps in sharing their positive and negative experiences (Hu et al., 2008) and influence the other online shoppers' buying behavior with respect to awareness about product(s) and features, opinions, attitudes, (re)purchase intention, and decisions (Hennig-Thurau and Walsh, 2003).
\end{abstract}

\section{Heuristic-Systematic Dual Process Model}

A dual-process framework deciphering the process of information flow, heuristicsystematic model (HSM) of persuasion, suggests that people can organise a piece of information in one of two ways: systematically (methodically) or heuristically (Chaiken, 1980). The present study uses this model to understand and examine the adoption of online consumer reviews. As per Chaiken (1980), this model explicates three comprehensive reasons explaining people's actions for processing information: accurateness, resistance, and impression motivation. Explaining systematic information processing, Todorov et al. (2002, p.196) observes that "people consider all relevant pieces of information, elaborate on these pieces, and form a judgment based on these elaborations." This path explains that information receivers put substantial mental energy in assessing the opinions and evaluating their legitimacy for decision making (Chaiken, 1980). The principle of sufficiency postulates that individuals are disposed towards performing systematic information processing when there is adequate impetus, capability, and cognitive resources (Chen et al., 1999). This indicates that extremely motivated people assess the opinions in a message. Subsequently, high quality messages might influence their decision making (Zhang and Watts, 2008).

Referring to heuristic information as a process, Tam and Ho (2005, p. 196) noted "people consider a few informational cues or even a single informational cue - and form a judgment based on these cues." This persuasion aspect of information processing postulates that the message receiver puts very less effort and depends on easily available signals (like quality of information source) to take decisions (Chaiken, 1980). This path is a preferred one for those people who would like to put lesser intellectual effort and expend greater energy only when needed (Bohner at al., 1995). They might spontaneously use heuristic signals that could be simple rules, to come to quick conclusions. As per Chen et al. (1999), heuristic rules can be connected with three components: the obtainability, ease of access, and applicability of information.

In brief, while systematic mode of information assessment takes place when an individual is enthused to understand and use the legitimate information being provided in a communication, heuristic mode depends on a small number of informational signals to judge a message (Todorov et al., 2002). 


\section{Online Reviews Adoption}

One of the first task that users pursue in online communities is information adoption. Using this process, individuals persistently participate in using information available online. Before making a shopping decision, consumers scan the thoughts and observations written by others (Pitta and Fowler, 2005) and/ or seek help by posting queries (Sussman and Siegal, 2003). As mentioned earlier, sixty-six per cent Indian online shoppers surveyed had noted that they were influenced by the reviews and comments (PwC, 2016). Hence, it is imperative to investigate the antecedents of online review adoption.

\section{Relationship between Review Characteristics, Perceived Usefulness and Perceived Value}

\section{Information credibility and Argument quality}

The e-retailers' webpages displaying various products, services, and related offerings generally contain reviews from other shoppers. Online buyers might browse through these reviews and comments, and use this information for making buying decisions. Existing literature has posited information credibility to be an essential element of a high-quality argument (Wathen and Burkell, 2002). Even though it is assessed by complex information processing (Llamero, 2014), information credibility is commonly described as the extent to which a consumer identifies a message as true, convincing, or accurate. Consumers observe those reviews useful that have higher information credibility. As per Cheung et al. (2008), this information credibility can be leveraged to build a highquality argument as well as convert visitors into buyers.

Now that almost everyone has the ability to publish information, there is a high likelihood of dilution of some of the online information quality. Argument quality talks about the influential power of opinions present in a review (Bhattacherjee and
Sanford, 2006). As per Negash et al. (2003), this quality is manifested by users' perception of value generated by a system. Earlier studies like Doll and Torkzadeh (1988) had observed that the content of information, correctness, presentation, and appropriateness determine the quality of information. With the advent of e-commerce, recent studies have added various dimensions in the measurement of information quality. As per web satisfaction framework, coherency, trustworthiness, and helpfulness of information define the quality of information (McKinney et al., 2002). Meanwhile, DeLone and McLean (2003) summarised the measures suggested by various studies as "accuracy, relevance, understandability, completeness, currency, dynamism, personalization, and variety."

Sirdeshmukh et al. (2002) noted that consumers display strong propensity to get the most value out of their decisions. In this regard, when shoppers are able to notice that the messages they are getting help in fulfilling their requirements are considered as valuable and important (Shen et al., 2013). As the customers are looking for apt information about the product/service, credible information and high quality of arguments would help them believe in the usefulness and value of the online reviews. Thus, in case of online reviews, it is anticipated that a review having higher information credibility and stronger quality of argument are considered as useful and valuable. Based on the above discussion, the following hypotheses are stated:

$\mathrm{H}_{1}$ : Information credibility has a positive effect on perceived usefulness of an online review.

$\mathrm{H}_{2}$ : Information credibility has a positive effect on perceived value of an online review.

$\mathrm{H}_{3}$ : Argument quality has a positive effect on perceived usefulness of an online review.

$\mathrm{H}_{4}$ : Argument quality has a positive effect on perceived value of an online review. 


\section{Quantity Sufficiency}

The number of reviews on a particular subject defines the volume of reviews. It has been noted that the volume of reviews in online media is much higher than the one on offline (Chen and Xie, 2008). Also, the former provides more complete and specific information than the later. Since, there is a vast accumulation of reviewed information on webpages, the volume of information is generally considered as determinant of information's truthfulness (King et al., 2014).

However, literature pivoted around the influence of volume of reviews on shoppers' buying intentions and decisions, has observed mixed results. Studies like Dellarocas et al. (2007), Sher and Lee (2009) and Zhu and Zhang (2010) have strongly posited the influence of information quantity on shoppers' buying intentions. In contrast, the study by Gauri et al. (2008) has reported that the proportion of favourable reviews has more influence on repurchase intention as against the absolute number of reviews. There are set of studies that have observed that shoppers consider the ratings and character of reviews rather than the sample size. Earlier too, a study by Godes and Mayzlin (2004) had pointed out that the spread of information is more important than the quantity of reviews. Later, Liu (2006) exemplified the positive relationship between the volume of reviews and revenues generated.

During the process of online shopping, when shoppers' observe that a particular product has received large quantity of reviews, they tend to take the heuristic path and expend less cognitive effort. This in turn leads to their belief that sufficient number of reviews are useful and are of great value to them. Hence, it is hypothesized that higher the number of reviews, better the shoppers' perception of the perceived usefulness and value of online reviews.

$\mathrm{H}_{5}$ : Quantity of reviews has a positive effect on perceived usefulness of an online review.
$\mathrm{H}_{6}$ : Quantity of reviews has a positive effect on perceived value of an online review.

\section{Relationship between Reviewer Characteristics, Perceived Usefulness and Perceived Value}

\section{Source Credibility}

The receiver's perception of trustworthiness towards the communicator of a message is referred to as source credibility (Chaiken, 1980). According to Petty and Cacioppo (1986), this reflects the extent of authenticity, competence, and truthfulness displayed by a message source. Establishing the role of credibility in its impact on information, earlier studies like Hovland and Weiss (1951) have noted that a high-credibility source has greater influence on receivers as compared to a low-credibility source. Later, Eagly and Chaiken (1993) observed that the number of communicator's positive attributes determines the persuasiveness of a message. Meanwhile, Ko et al. (2005) noted that information shared by highly trustworthy sources facilitates knowledge transfer as it is professed to be beneficial and reliable.

Earlier studies have shown that when consumers follow the peripheral route, they tend to get prejudiced by the source's appeal, amiability, and trustworthiness (Filieri and McLeay, 2014). In this paper, authors have used expertise and trustworthiness of a message communicator as important elements representing source credibility.

In the present virtual setting, everyone has the liberty to share, express and post their state of mind towards other people, products, brands or even companies, without revealing their actual identification. Hence, information users have discretion in determining the credibility of the review writer and can decide whether to accept or discard the shared information.

In line with the HS model, shoppers following the heuristic path of information processing tend to rely on credible 
Influence of Information and Source Characteristics on Review Adoption / Vijay et al.

information sources to avoid expending greater cognitive effort. Hence, when the reviews are provided by credible sources, consumers tend to attach greater value to them. So in case, online visitors consider that the reviews have been written by shoppers' having high-credibility, they will then perceive the reviews to be useful and valuable:

$\mathrm{H}_{7}$ : Source credibility has positive impact on perceived usefulness of reviews.

$\mathrm{H}_{8}$ : Source credibility has positive impact on perceived value of reviews.

\section{Relationship between Perceived Usefulness, Perceived Value and Online Review Adoption}

\section{Perceived Usefulness}

Perceived usefulness is a person's belief that by means of a new technology/tool/process or any other element, his/her performance will increase over time. This is an essential predictive element associated with the user's adoption of technology or like, and is significantly correlated with its usage (Davis, 1989). A study by Moon and Kim (2001) posited that perceived usefulness has a substantial impact on shoppers' intention to adopt the online platform. Hence, perceived usefulness, one of technology acceptance model's vital factor, can be used to analyse the adoption of online reviews. In an online environment, shoppers can share their ideas, thoughts and feelings about various products or services in the form of online review at e-retailer's website or any other third-party review website. Customers would have their own beliefs regarding the usefulness of such reviews and the values that can be derived from them, which would help other customers in adopting those reviews (Moon and Kim, 2001). Consequently, if online shoppers assume that testimony or review within a website is useful and valuable, they will have better intent of adopting them. The belief of usefulness of reviews would form shoppers' intentions towards adopting them. Based on these arguments, the following hypothesis is formulated:

$\mathrm{H}_{9}$ : Perceived usefulness positively impacts the adoption of online reviews

\section{Perceived Value}

Perceived value is defined as "consumer's perceptions of what is received and what is given determine the consumer's overall assessment of the utility of a product or service," (Zeithaml, 1988). As per Wang and Strong (1996), customers perceive cue to be value adding only if the said information is beneficial and it creates leverage for them. Shoppers will be prepared to adopt online reviews only when the reviews have some value for them (Scherer et al., 2015). As against the marketers' induced positive communication, such reviews may be negative and critical too. The reviews may strengthen the buyers' power to make informed decisions (Filieri and McLeay, 2014). While, perceived usefulness in the context of online reviews has been stated as shoppers' belief that using the reviews will enhance their shopping experience (Elwalda et al., 2016), perceived value, on the other hand is based on shoppers' perception about the total benefits gained from online reviews (Xu and Yao, 2015).

Since perceived value is considered to be an essential element for comprehending shoppers' decision making behaviour in adoption of reviews, hence it can be stated that reviews' perceived value would be pertinent in explaining the reasons' shoppers adopt them. If the shoppers perceive greater value from such online reviews, their likelihood of adoption of online review will be higher. So the following hypothesis is being proposed:

$\mathrm{H}_{10}$ : Perceived value positively impacts the adoption of online reviews

The hypothesised research model is shown in figure 1. 


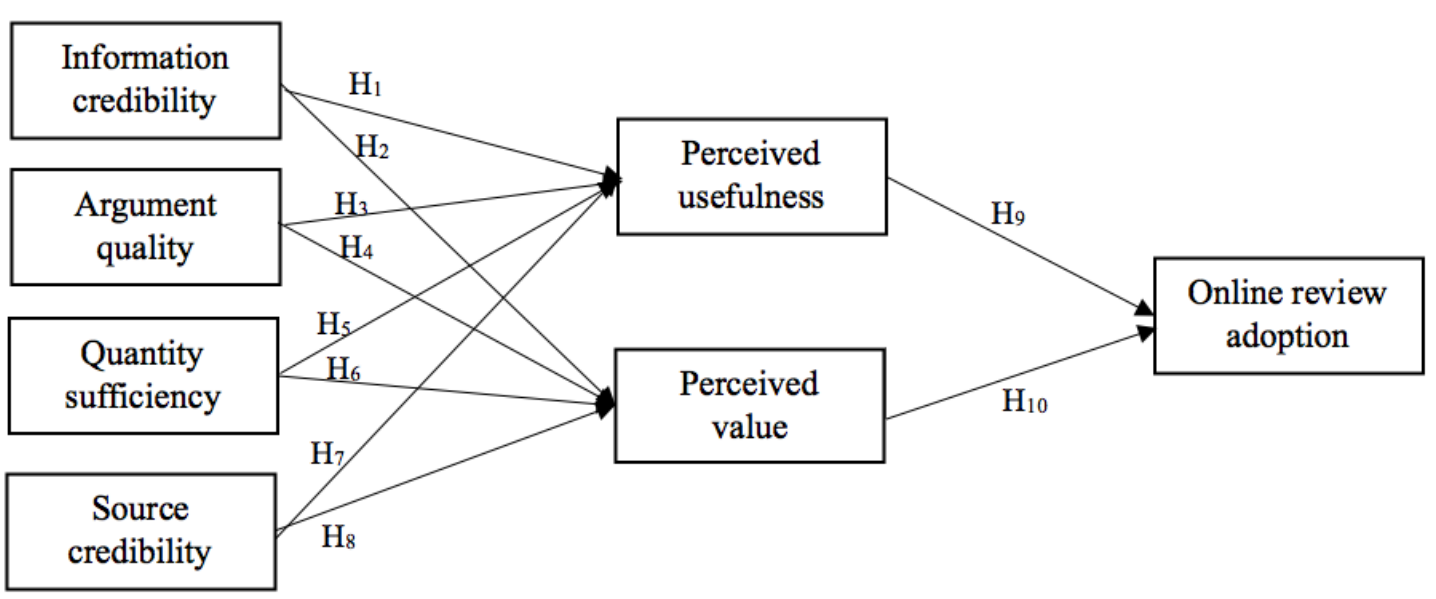

\section{Figure 1 - Hypothesised Model}

\section{Research Methodology}

\section{Measurement Items}

From the review of literature, the relevant constructs and their respective measurement scales were identified. These included antecedent factors - information credibility, quantity sufficiency, argument quality and source credibility; mediators perceived usefulness and perceived value; and online review adoption as the dependent variable. Table 1 presents the scales that were used for measuring these variables.

\section{Table 1 - Construct and Respective Scales Used}

\begin{tabular}{|l|l|}
\hline Construct & Studies \\
\hline Information Credibility & Cheung et al. (2009) \\
\hline Argument Quality & Bhattacherjee and Sanford (2006) and Cheung et al. (2008) \\
\hline Quantity Sufficiency & Song et al. (2014) \\
\hline Source Credibility & Wu and Shaffer (1987) \\
\hline Perceived Usefulness & Gefen et al. (2003) and Koufaris (2002) \\
\hline Perceived Value & Ryu et al. (2008) \\
\hline Online Reviews Adoption & Cheung et al. (2009) \\
\hline
\end{tabular}

Before proceeding towards data collection, the survey instrument was pilot tested among twenty-five doctoral students. All the validity and reliability coefficients were found to be acceptable. The study items were measured on a seven-point Likert scale, ranging from strongly disagree (1) to strongly agree (7). The data was collected through personal interviews with young business executives and students pursuing their post-graduate studies across four major Indian metropolitan cities during the period of four months September December 2016. The sample was confined to those Internet shoppers who had previously used online consumer reviews 
Influence of Information and Source Characteristics on Review Adoption / Vijay et al.

while shopping at a particular e-retailer (Amazon.in). The survey began with an introductory statement that asked respondents to provide their responses and assured them of confidentiality. Besides soliciting response on select measurement items, respondents were requested to share demographic information too. Discarding the incomplete and erroneously filled sixteen questionnaires, 320 questionnaires were used for further data analysis.

\section{Data Analysis and Results}

\section{Demographic Profile of the Respondents}

The profile of the survey respondents' is presented in Appendix (Annexure 1). Twothird of the sample consisted of male respondents. More than ninety per cent of the respondents were below thirty years of age. Nearly forty-one percent of respondents had monthly income more than INR150,000. These demographics adequately reflect the young market that strongly associate with online buying (PTI, 2016). Majority of the respondents had been buying online at least once in a month.

\section{Measurement model}

Confirmatory factor analysis was undertaken to assess the constructs' validities - convergent and discriminant. From the Table 2, we note that the composite reliability scores ranged between 0.70 and 0.90 , which are above the cut-off criterion of 0.7 (Hair et al., 2006). Similarly, values of average variance extracted (AVE) for all the constructs were above the minimum required level of 0.5 (Chin, 1998). The results of these two measures evidence convergent validity (Fornell and Larcker, 1981). Since, all the constructs had a values greater than the recommended 0.6 (Hair et al., 2006), the scales used in the study are considered to be highly reliable.

Apart from measuring the reliability and validity of the constructs, various fit indices were measured to check for the suitability and fit of the data with the proposed model. The ratio of chi square minimum to degree of freedom (CMIN/DF) was 2.32. Being below the cut-off criterion of 3.00 (Hair et al., 2006), it indicated a good fit between the data and the proposed model. Hair et al. (2006) recommended that other indices GFI (goodness-of-fit index), CFI (comparative fit index), IFI (incremental fit index) and TLI (Tucker-Lewis index) should be greater than 0.9; and RMSEA should be less than 0.08 . With the values for these fit indices being - GFI (= 0.899), AGFI (= $0.854)$, IFI (=0.958), CFI $(=0.957)$, Normed Fit Index (NFI) (=0.928), TLI (=0.944) and RMSEA $(=0.062)$, the proposed model is considered to have a good fit with the data.

As suggested by Ping (2004), convergent and discriminant validities were checked for assessing construct validity. Convergent validity is assessed by measuring the average variance extracted, which should be above the minimum level of 0.50 (Fornell and Larcker, 1981). From Table 2, it can be seen that the AVE values are between 0.62 and 0.75 . This confirms convergent validity of the dataset. Further, discriminant validity was assessed using the method suggested by Fornell and Larcker (1981), where square root of average variance extracted for every factor was calculated. These values should be greater than the factor correlation coefficients. Table 3 presents the results of discriminant analysis.

From Table 3 , it is noted that the diagonal values exceed all the values in the respective columns, indicating the confirmation of discriminant validity.

Since the data has been collated from a single source at one point of time and related to the perceptual measures, there is high potential of common method bias. It was decided to undertake Harman's one factor test on the constructs of the research model (Podsakoff et al., 2003; Podsakoff and Organ, 1986). From the result of principal components analysis, it is observed that the factors cumulatively 
Vijay et al.: An Empirical Examination of the Influence of Information and Sour

Influence of Information and Source Characteristics on Review Adoption / Vijay et al.

accounted for seventy-six percent of the variance and the first factor alone contributed to forty-three percent of the variance explained. This being below the cut-off of fifty percent, common method bias was not present in the case.

\section{Table 2 - Measurement Model (CFA)}

\begin{tabular}{|c|c|c|c|c|}
\hline Factor and Items & $\begin{array}{l}\text { Factor } \\
\text { Loadings }\end{array}$ & a & $\begin{array}{l}\text { Average } \\
\text { Variance } \\
\text { Extracted }\end{array}$ & $\begin{array}{l}\text { Composite } \\
\text { Reliability }\end{array}$ \\
\hline Information Credibility & & 0.864 & 0.69 & 0.87 \\
\hline I think online reviews are factual. & 0.697 & & & \\
\hline I think online reviews are accurate. & 0.943 & & & \\
\hline I think online reviews are credible. & 0.842 & & & \\
\hline Argument Quality & & 0.856 & 0.62 & 0.87 \\
\hline $\begin{array}{l}\text { Online reviews provide complete information about the } \\
\text { product or service. }\end{array}$ & 0.768 & & & \\
\hline $\begin{array}{l}\text { Online reviews provide timely information about the } \\
\text { product or service. }\end{array}$ & 0.800 & & & \\
\hline $\begin{array}{l}\text { Online reviews provide accurate information about the } \\
\text { product or service. }\end{array}$ & 0.880 & & & \\
\hline $\begin{array}{l}\text { Online reviews provide comprehensive information about } \\
\text { the product or service. }\end{array}$ & 0.704 & & & \\
\hline Quantity Sufficiency & & 0.884 & 0.73 & 0.89 \\
\hline The website has enough reviews. & 0.897 & & & \\
\hline The number of reviews on the website is adequate. & 0.911 & & & \\
\hline There are ample reviews on the website. & 0.753 & & & \\
\hline Source Credibility & & 0.857 & 0.67 & 0.86 \\
\hline $\begin{array}{l}\text { People who left comments in Amazon.co.in are experts in } \\
\text { evaluating products and services. }\end{array}$ & 0.666 & & & \\
\hline $\begin{array}{l}\text { People who left comments in Amazon.co.in are } \\
\text { trustworthy. }\end{array}$ & 0.865 & & & \\
\hline People who left comments in Amazon.co.in are reliable. & 0.901 & & & \\
\hline Perceived Usefulness & & 0.910 & 0.75 & 0.90 \\
\hline $\begin{array}{l}\text { Online customer reviews enhance my online shopping } \\
\text { effectiveness. }\end{array}$ & 0.845 & & & \\
\hline $\begin{array}{l}\text { Online customer reviews increase my effectiveness when } \\
\text { shopping online. }\end{array}$ & 0.833 & & & \\
\hline I find using online customer reviews useful. & 0.917 & & & \\
\hline Perceived Value & & 0.906 & 0.70 & 0.90 \\
\hline $\begin{array}{l}\text { Compared to the time I need to spend, the use of online } \\
\text { reviews is worthwhile to me. }\end{array}$ & 0.832 & & & \\
\hline $\begin{array}{l}\text { Compared to the effort I need to put in, the use of online } \\
\text { reviews is beneficial to me. }\end{array}$ & 0.822 & & & \\
\hline $\begin{array}{l}\text { Considering the hassle that I may experience, the use of } \\
\text { online reviews is helpful to me. }\end{array}$ & 0.843 & & & \\
\hline Overall, the use of online reviews delivers me good value. & 0.854 & & & \\
\hline Online Reviews Adoption & & 0.869 & 0.69 & 0.87 \\
\hline $\begin{array}{l}\text { Information from online reviews contributes to my } \\
\text { knowledge of the discussed product/service. }\end{array}$ & 0.783 & & & \\
\hline $\begin{array}{l}\text { Online reviews make it easier for me to make a purchase } \\
\text { decision (e.g. purchase or not purchase). }\end{array}$ & 0.855 & & & \\
\hline $\begin{array}{l}\text { Online reviews have enhanced my effectiveness in } \\
\text { making a purchase decision. }\end{array}$ & 0.846 & & & \\
\hline
\end{tabular}




\section{Table 3 - VIF and Test of Discriminant Analysis}

\begin{tabular}{|l|c|c|c|c|c|c|c|c|}
\hline \multicolumn{1}{|c|}{ Construct } & VIF & IC & AQ & QS & SC & PU & PV & ORA \\
\hline Information Credibility & 1.865 & $\mathbf{0 . 8 3 0 ^ { * }}$ & & & & & & \\
\hline Argument Quality & 2.091 & 0.520 & $\mathbf{0 . 7 8 7 ^ { * }}$ & & & & & \\
\hline Quantity Sufficiency & 1.284 & 0.347 & 0.419 & $\mathbf{0 . 8 5 4 ^ { * }}$ & & & & \\
\hline Source Credibility & 1.859 & 0.576 & 0.558 & 0.317 & $\mathbf{0 . 8 1 8 ^ { * }}$ & & & \\
\hline Perceived Usefulness & 2.801 & 0.611 & 0.592 & 0.400 & 0.589 & $\mathbf{0 . 8 6 6 ^ { * }}$ & & \\
\hline Perceived Value & 2.777 & 0.547 & 0.661 & 0.403 & 0.538 & 0.75 & $\mathbf{0 . 8 3 6 ^ { * }}$ & \\
\hline Online Reviews Adoption & --- & 0.586 & 0.584 & 0.408 & 0.509 & 0.75 & 0.70 & $\mathbf{0 . 8 3 0}^{*}$ \\
\hline
\end{tabular}

Notes: * Diagonal values are square root of AVE, others are correlation coefficients.

\section{Structural Model}

Once the measurement model was confirmed to be satisfactory, the assessment of hypothesised structural model was undertaken using structural equation modelling (SEM) with AMOS 22.0. Since chi-square statistics is dependent on the size of sample (Hair et al., 2006), the same is considered to be insufficient index to evaluate the model. Hence, the structural model's fit is determined using fit indices GFI, AGFI, NFI, TLI, CFI, RMSEA, and RMR (Hair et al., 2006). Indices results for the present study show that GFI $=0.88$, $\mathrm{AGFI}=0.84, \mathrm{CFI}=0.94, \mathrm{NFI}=0.91, \mathrm{TLI}=$ 0.93, RMSEA $=0.07$, and RMR $=0.07$, which reflect a good fit with the model (Hair et al., 2010).

The results of the hypothesised model are present in Fig. 2. The standardized coefficients and their significance have been illustrated for each hypothesis.

The results of the structural model supported all the proposed hypotheses. The same have been reflected in Table 4 .

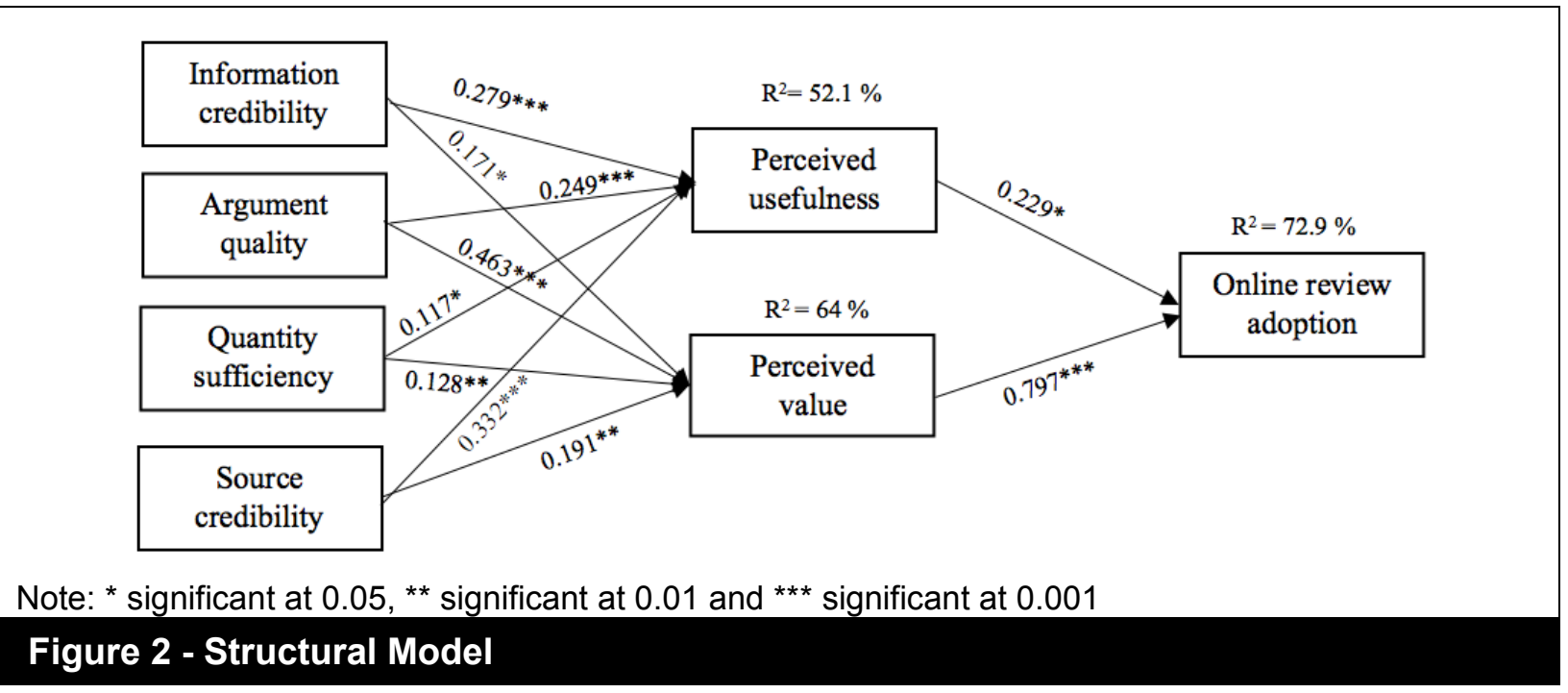

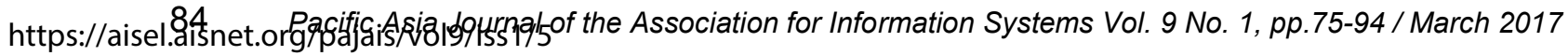




\begin{tabular}{|l|l|c|c|}
\hline Table 4 - Structural Parameter Estimates \\
\hline Hypothesis & Estimate & $\begin{array}{c}\text { Critical } \\
\text { ratio }\end{array}$ & Result \\
\hline $\mathrm{H}_{1}:$ Information credibility $\longrightarrow$ Perceived usefulness & 0.279 & $4.032^{* * *}$ & Accepted \\
\hline $\mathrm{H}_{2}:$ Information credibility $\longrightarrow$ Perceived value & 0.171 & $2.426^{*}$ & Accepted \\
\hline $\mathrm{H}_{3}:$ Argument quality $\longrightarrow$ Perceived usefulness & 0.249 & $3.884^{* * *}$ & Accepted \\
\hline $\mathrm{H}_{4}:$ Argument quality $\longrightarrow$ Perceived value & 0.463 & $6.311^{* * *}$ & Accepted \\
\hline $\mathrm{H}_{5}:$ Quantity sufficiency $\longrightarrow$ Perceived usefulness & 0.117 & $2.478^{*}$ & Accepted \\
\hline $\mathrm{H}_{6}:$ Quantity sufficiency $\longrightarrow$ Perceived value & 0.128 & $2.633^{* *}$ & Accepted \\
\hline $\mathrm{H}_{7}:$ Source credibility $\longrightarrow$ Perceived usefulness & 0.332 & $5.413^{* * *}$ & Accepted \\
\hline $\mathrm{H}_{8}:$ Source credibility $\longrightarrow$ Perceived value & 0.191 & $3.068^{* *}$ & Accepted \\
\hline $\mathrm{H}_{9}:$ Perceived usefulness $\longrightarrow$ Online review adoption & 0.229 & $2.451^{*}$ & Accepted \\
\hline $\mathrm{H}_{10}:$ Perceived value $\longrightarrow$ Online review adoption & 0.797 & $7.733^{* * *}$ & Accepted \\
\hline $\begin{array}{l}\text { Goodness of fit indices: CMIN/df2.55; CFI=0.94; GFI=0.88, AGFI=0.84; NFI=0.91; IFI = 0.95; TLI = } \\
0.93 ; \text { RMSEA = 0.07 }\end{array}$ & & \\
\hline
\end{tabular}

All four antecedent factors, namely information credibility $(b=0.279, p<0.000)$, argument quality $(b=0.249, \quad p<0.000)$, quantity sufficiency $(b=0.117, p<0.05)$ and source credibility $(b=0.332, p<0.001)$ were found to have positive impact on perceived usefulness of reviews. Therefore, $\mathrm{H}_{1}, \mathrm{H}_{3}, \mathrm{H}_{5}$ and $\mathrm{H}_{7}$ were supported. Similarly, these factors - information credibility $(b=0.171$, $p<0.05)$, argument quality $(b=0.463$, $p<0.000)$, quantity sufficiency $(b=0.128$, $p=0.502)$ and source credibility $(b=0.191$, $p<0.000)$ positively influenced reviews' perceived value, indicating the acceptance of $\mathrm{H}_{2}, \mathrm{H}_{4}, \mathrm{H}_{6}$ and $\mathrm{H}_{8}$. Further, the two variables - reviews' perceived usefulness $(b=0.156, p<0.05)$ and value $(b=0.755$, $p<0.01)$ were noted to have significant positive impact on the adoption of online reviews among Indian shoppers.

With reference to perceived usefulness, source credibility has the highest influence ( $\beta=0.332^{* * *}$ ), followed by information credibility, argument quality and quantity sufficiency. On the other hand, argument quality $\left(\beta=0.463^{* * *}\right)$ contributes most to perceived value of reviews. Source credibility, information credibility and quantity sufficiency have relatively lesser influence in the formation of perceived value. Even the impact of two mediating factors perceived usefulness and perceived value on online review adoption is not equal. Reviews' perceived value $\left(\beta=0.797^{* * *}\right)$ has significantly more influence on the adoption of reviews as against that of perceived usefulness.

As a supplementary analysis, the mediating effects of reviews' perceived usefulness and value were also tested using the method suggested by Hayes (2009). From the results, it is observed that both perceived usefulness and perceived value mediated the relationship between the predictor variables and online review adoption (Refer Table 5).

The four antecedent variables - information credibility, argument quality, volume of reviews and source credibility, explained 52.1 percent in perceived usefulness and 64 percent in perceived value. Overall, variance explained in online review adoption was 72.9 percent (Refer figure 2). 


\begin{tabular}{|c|c|c|c|c|c|c|c|c|c|c|}
\hline \multirow{3}{*}{$\begin{array}{l}\text { Predictor } \\
\text { variables }\end{array}$} & \multirow{2}{*}{\multicolumn{3}{|c|}{$\begin{array}{c}\text { Perceived usefulness } \\
\text { Effect }\end{array}$}} & \multirow{2}{*}{\multicolumn{3}{|c|}{$\frac{\text { Perceived value }}{\text { Effect }}$}} & \multirow{2}{*}{\multicolumn{3}{|c|}{$\begin{array}{c}\text { Online review adoption } \\
\text { Effect }\end{array}$}} & \multirow{3}{*}{$\begin{array}{c}\begin{array}{c}\text { Significance } \\
\text { of indirect } \\
\text { effect }\end{array} \\
p \text {-value } \\
\end{array}$} \\
\hline & & & & & & & & & & \\
\hline & Indirect & Direct & Total & Indirect & Direct & Total & Indirect & Direct & Total & \\
\hline $\begin{array}{l}\text { Information } \\
\text { credibility }\end{array}$ & 0.00 & 0.279 & 0.279 & 0.00 & 0.171 & 0.171 & 0.200 & 0.095 & 0.295 & 0.018 \\
\hline $\begin{array}{l}\text { Argument } \\
\text { quality }\end{array}$ & 0.00 & 0.249 & 0.249 & 0.00 & 0.463 & 0.463 & 0.426 & -0.036 & 0.390 & 0.018 \\
\hline $\begin{array}{l}\text { Quantity } \\
\text { sufficiency }\end{array}$ & 0.00 & 0.117 & 0.117 & 0.00 & 0.128 & 0.128 & 0.129 & 0.009 & 0.138 & 0.009 \\
\hline $\begin{array}{l}\text { Source } \\
\text { credibility }\end{array}$ & 0.00 & 0.332 & 0.332 & 0.00 & 0.191 & 0.191 & 0.228 & -0.154 & 0.075 & 0.010 \\
\hline $\begin{array}{l}\text { Perceived } \\
\text { usefulness }\end{array}$ & -- & -- & -- & -- & -- & -- & -- & 0.229 & 0.229 & -- \\
\hline $\begin{array}{l}\text { Perceived } \\
\text { value }\end{array}$ & -- & -- & -- & -- & -- & -- & -- & 0.797 & 0.797 & -- \\
\hline
\end{tabular}

\section{Discussion and Conclusion}

The primary aim of the study is to gain deeper understanding of adoption of online reviews at the individual level using the dual process of heuristic-systematic model. In particular, it examines the role of systematic and heuristic factors in influencing shoppers' decision-making towards adoption of reviews. Though the Indian online retail market has been growing at an exponential rate (PTI, 2016), none of the existing studies has attempted to identify the antecedents influencing the adoption of online reviews in Indian perspectives. Globally too, extant literature has focussed more on the Elaboration Likelihood information processing model (ELM) to understand the adoption of online reviews (Cheung and Thadani, 2012). The present study, on the other hand, has used the Heuristic-Systematic Model to investigate the influence of the information credibility, argument quality, quantity sufficiency and source credibility of online reviews on shoppers' review adoption behaviour.

Deciphering the impact of such influencing factors is pertinent for both formulation of theory and online marketers. The findings show that the four attributes of reviews (independent variables) have significant, but indirect influence on Indian customers' intentions to adopt online reviews. These are information credibility, argument quality, quantity sufficiency and source credibility. The first two pertain to the category of systematic factors, while quantity sufficiency and source credibility fall in the category of heuristic factors. None of these have any direct significant influence on review adoption. The influence of these factors on shoppers' adoption of online reviews is mediated through reviewers' perception of usefulness and value of such reviews. It is worth noting that all the four antecedent variables influence both of these mediating variables, albeit of unequal significance.

With reference to perceived usefulness, source credibility was found to have the highest influence, followed by information credibility, argument quality and quantity sufficiency. On the other hand, argument quality contributed most to perceived value of reviews. Source credibility, information credibility and quantity sufficiency have relatively lesser influence in the formation of perceived value. Even the two mediating factors - perceived usefulness and perceived value have unequal impact on online review adoption. Reviews' perceived value has significantly more influence on the adoption of reviews as against that of perceived usefulness. 
This paper on Indian online shoppers cements some of the observations of earlier studies. Wathen and Burkell (2002) and Llamero (2014) have also reported the significant influence of information credibility on both perceived usefulness and perceived value of reviews. Dong and Hayes (2011) have posited a noteworthy impact of quantity sufficiency (number of reviews) on both the mediators. Similarly, argument quality and source credibility have also been posited to have an effect on usefulness and value of reviews (Xu and Yao, 2015; Cheung et al., 2008).

Despite of some commonalities with the existing studies, the present study markedly differs as it uses four major structural variables - information characteristics (credibility, quality and sufficiency) and source characteristics (credibility) in one study. All these four predictor variables were selected as they satisfy shoppers' different needs from informational cues and each of these cannot substitute for other variable. Earlier studies have used either one or two of the variables only, to measure/ decipher the influence on consumers' adoption of online reviews (e.g. $\mathrm{Xu}$ and Yao, 2015; Cheung et al., 2008). These have mostly considered argument quality to be core, and reviews' credibility and quantity as the peripheral cues (Zhang et al., 2014).

Also, this study has noted the mediating impact of both the constructs - reviewers' perceived usefulness and value on adoption of online reviews. In contrast, earlier studies have investigated the direct and indirect impact of predictor variables on the final decision through either of the two mediators (for e.g. Xu and Yao, 2015; Cheung et al., 2008). Those studies have not taken into account the role of perceived usefulness and perceived value together. Besides verifying such relations, the current study has indicated that the four predictor variables positively affect reviews' perceived usefulness and value, and final decision of the adoption of online reviews.
Expanding the works of Davis (1989), Gefen et al. (2003) and Pavlou (2003), the present papers establishes that customers' willingness to accept online reviews before purchasing is strongly influenced by online reviews' perceived usefulness and value. The earlier studies have reported only the strong influence of reviews' perceived usefulness on review adoption behaviour. Contrarily, this paper establishes that Indian online shoppers consider reviews' perceived value more than its usefulness in deciding for adoption of such reviews.

The results of this study reinforce the view that information credibility and argument quality (systematic factors) and, quantity sufficiency and source credibility (heuristic factors) are key determining factors of review adoption. On the whole, shoppers observe and inspect online reviews to form opinions about reviews' usefulness and value. Acting as an important supplemental information, useful reviews assist buyers to decrease ambiguity. They also get assistance from such influential reviews (argument quality) that counsels them with explicit causality and facilitate in following convincing recommendations. Besides this, consumers also make use of heuristic mode of information processing to simplify their decision-making. Source credibility is one such cue. Upon finding the source of review to be credible, online shoppers' intention to adopt reviews increases.

\section{Implications}

The authors believe that this research would expand the knowledge by contributing to the extant literature through theoretical implications. By using the heuristicsystematic model to identify the antecedents of e-shoppers' review adoption behaviour, this study has advanced the understanding and applicability of this dual process persuasion model. In agreement with the study by Zhang et al. (2014), the present research has advanced the influence of online reviews through heuristic 
systematic model at an individual level. The study has posited significant influence of information credibility and argument quality (the systematic factors) and, source credibility and quantity sufficiency (the heuristic factors) on shoppers' review adoption albeit through mediating variables - perceived value and perceived usefulness of reviews. The results are congruent with the "additivity effect" of the HS model, which advocates the effects of cognitive as well as cue-related features on individual's decision making (Chaiken and Maheswaran, 1994).

The statistical evidence with respect to the effect of systematic factors - argument quality and information credibility on the mediating (and dependent variables) approves the point that content in the online review frequently helps shoppers in their decision-making. The results of the study also observed the influence through heuristic modes of information processing on shoppers' review adoption behaviour. Both the heuristic factors - quantity sufficiency and source credibility had substantial direct effect on reviews' perceived usefulness and value, and significant (indirect) effect on online review adoption.

The significant contribution of the study is the application of heuristic-systematic model on shoppers online review adoption process. The four antecedents - information credibility and argument quality (systematic factors), volume of reviews and source credibility (heuristic factors) explained 52.1 percent variance in perceived usefulness and 64 percent in perceived value. Overall, variance explained in online review adoption was 72.9 percent. This confirms the cooccurrence of both the elements of HSM model.

The findings of the study also enhanced the literature by highlighting the mediating role of the two mediators - perceived usefulness and perceived value in the relationship between various antecedents and their influence on adoption of online reviews. On an individual construct basis, it is noted that argument quality has the highest impact on perceived value and source credibility on perceived usefulness. On the other hand, quantity sufficiency as a factor has least influence in both the cases. Considering the cumulative effect of the heuristic and systematic factors, it is observed that for both the mediators, systematic factors (information credibility and argument quality) have greater influence.

The study also suggests that online shoppers give more weightage to value as against usefulness of reviews. Besides the confirmation of cumulative role of systematic and heuristic factors on adoption of online reviews through perceived usefulness and value as mediators, the study is pioneer in validating the scales of all the seven constructs used in the context of emerging market of India. The scales had originally been developed and tested in the advanced markets.

This study presents some practical implications to online retailers for strategizing their action plans. E-retailers would be able to comprehend the effect of online reviews through the application of the model used and the findings therein. To be able to augment the influence of systematic mode, it is imperative for such retailers to pay special attention to the reviews generated on web portals by online shoppers. Specifically, online managers must monitor the credibility and quality of the information provided through the written arguments. The quality must be measured using the indices of informativeness and persuasiveness of these reviews. Less credible or poor argumentative reviews can deter shoppers' behavior.

Among the two mediators - perceived usefulness and perceived value, the study suggests that reviews' perceived value had significantly stronger impact on shoppers' review adoption behaviour. Hence, eretailers should endeavour to make the shoppers realize the value (time and effort) they are getting through these online 
testimonies. Since quality of an argument has emerged to be the most significant influencer, the retailers must work on highlighting the quality reviews from the users. The better a review's argument quality, the higher is their likelihood of adopting those reviews. On the contrary, poor quality of arguments will reduce the probability of adoption of reviews. This would be the case with shoppers who are willing to spend greater cognitive skills to understand the message and rely on systematic mode of information processing. On the other hand, shoppers who do not want to expend energy in understanding a message would rely on the heuristic mode of information processing. In such a case, they will be focussing more on the credibility of the source and the quantity of the reviews on the website.

Reference the direct and indirect effects of heuristic cues on shoppers' review adoption behaviour, e-retailers should make it easy for consumers to assess the credibility of the source and quantity of reviews on the web portals. Websites can offer signals, suggestions and tools to support buyers in identifying the credibility of reviewers. Also, to augment the effect of volume of reviews, online managers must constantly show the number of reviews associated with popular products on their website. This would get shoppers' attention as they would take note of the products with a high number of online reviews.

Finally, based on the results and findings of this study, it can be suggested to e-retailers to focus on motivating shoppers for their involvement in review generation. The credibility of information and argument quality will only improve when consumers are motivated enough to share their thoughts and write reviews on the web portal. In order to increase the quantity of good reviews on their sites, it becomes pertinent for e-retailers to provide specific incentives to shoppers who provide reviews. It is equally important for the online retailers to monitor the credibility of the review providers and weed out untrustworthy reviews.

\section{Limitations and Future Research}

Though every care has been taken while conducting the study, some limitations do exist that may be considered as a guide for future researchers. Regarding the external validity of scales that have been developed in developed markets, the present study has validated the same in Indian context scales. Still, in order to further generalise the findings, studies should be undertaken in other emerging markets. Also, the data for the study was collected through a survey based questionnaire. Future researchers should undertake experimental design studies to further validate the findings. The present study didn't use product category as a variable for research. It would be interesting to note the difference in shoppers' review adoption behaviour with respect to different product categories. Finally, instead of just relying on crosssectional data, future studies can conduct longitudinal studies. The reviews presented on e-retailer's site can differ from the reviews available on other third party sites. Future studies can take into consideration reviews available on different sites and examine the impact of various antecedents on shoppers' behavioural intentions.

\section{References}

Bhattacherjee, A., and Sanford, C. (2006). "Influence processes for information technology acceptance: An elaboration likelihood model," MIS quarterly, 30(4), pp. 805-825.

Bohner, G., Moskowitz, G. B., and Chaiken, S. (1995). "The interplay of heuristic and systematic processing of social information," European review of social psychology, 6(1), pp. 33-68. 
Chaiken, S. (1980). "Heuristic versus systematic information processing and the use of source versus message cues in persuasion," Journal of personality and social psychology, 39(5), pp. 752-766.

Chaiken, S., and Maheswaran, D. (1994). "Heuristic processing can bias systematic processing: effects of source credibility, argument ambiguity, and task importance on attitude judgment," Journal of personality and social psychology, 66(3), pp. 460-473.

Chen, S., Duckworth, K., and Chaiken, S. (1999). "Motivated heuristic and systematic processing," Psychological Inquiry, 10(1), pp. 44-49.

Chen, Y., and Xie, J. (2008). "Online consumer review: Word-of-mouth as a new element of marketing communication mix," Management science, 54(3), pp. 477-491.

Cheung, C. M., Lee, M. K., and Rabjohn, N. (2008). "The impact of electronic word-of-mouth: The adoption of online opinions in online customer communities," Internet

Research, 18(3), pp. 229-247.

Cheung, M. Y., Luo, C., Sia, C. L., and Chen, H. (2009). "Credibility of electronic word-of-mouth: Informational and normative determinants of on-line consumer recommendations," International Journal of Electronic Commerce, 13(4), pp. 9-38.

Cheung, C. M., and Thadani, D. R. (2012). "The impact of electronic word-ofmouth communication: A literature analysis and integrative model," Decision Support Systems, 54(1), pp. 461-470.

Chin, W. W. (1998). "Commentary: Issues and opinion on structural equation modeling," MIS Quarterly, 22(1), pp. vii-xvi.
Davis, F. D. (1989). "Perceived usefulness, perceived ease of use, and user acceptance of information technology," MIS quarterly, 13(3), pp. 319-340.

Delone, W. H., and McLean, E. R. (2003). "The DeLone and McLean model of information systems success: a tenyear update," Journal of management information systems, 19(4), pp. 9-30.

Dellarocas, C., Zhang, X. M., and Awad, N. F. (2007). "Exploring the value of online product reviews in forecasting sales: The case of motion pictures," Journal of Interactive marketing, 21(4), pp. 23-45.

Doll, W. J., and Torkzadeh, G. (1988). "The measurement of end-user computing satisfaction," MIS quarterly, 12(2), pp. 259-274.

Dong, X., and Hayes, C. C. (2011, July). Using uncertainty to inform information sufficiency in decision making. In International Conference on Engineering Psychology and Cognitive Ergonomics (pp. 294-302). Springer Berlin Heidelberg.

Eagly, A. H., and Chaiken, S. (1993). The Psychology of Attitudes Harcourt Brace Jovanovich College Publishers. Fort Worth, TX.

Elwalda, A., Lü, K., and Ali, M. (2016). "Perceived derived attributes of online customer reviews," Computers in Human Behavior, 56(1), pp. 306-319.

Filieri, R., and McLeay, F. (2014). "E-WOM and accommodation an analysis of the factors that influence travelers' adoption of information from online reviews," Journal of Travel Research, 53(1), pp. 44-57.

Fornell, C., and Larcker, D. F. (1981). "Evaluating structural equation models with unobservable variables and measurement error," Journal of marketing research, 18(1), pp. 39-50. 
Gauri, D. K., Bhatnagar, A., and Rao, R. (2008). "Role of word of mouth in online store loyalty," Communications of the ACM, 51(3), pp. 89-91.

Gefen, D., Karahanna, E., and Straub, D. W. (2003). "Trust and TAM in online shopping: an integrated model," MIS quarterly, 27(1), pp. 51-90.

Godes, D., and Mayzlin, D. (2004). "Using online conversations to study word-ofmouth communication," Marketing science, 23(4), pp. 545-560.

Hair, J. F., Black, W. C., Babin, B. J., Anderson, R. E., and Tatham, R. L. (2006). Multivariate data analysis, 6th Edition. Pearson Education, New Jersey.

Hayes, A. F. (2009). "Beyond Baron and Kenny: Statistical mediation analysis in the new millennium." Communication monographs, 76(4), pp. 408-420.

Hennig-Thurau, T. and Walsh, G. (2003). "Electronic word-of-mouth: Motives for and consequences of reading customer articulations on the Internet," International Journal of Electronic Commerce, 8(2), pp. 51-74.

Hovland, C. I., and Weiss, W. (1951). "The influence of source credibility on communication effectiveness," Public opinion quarterly, 15(4), pp. 635-650.

$\mathrm{Hu}, \mathrm{N}$., Liu, L., and Zhang, J. J. (2008). "Do online reviews affect product sales? The role of reviewer characteristics and temporal effects," Information Technology and Management, 9(3), pp. 201-214.

King, R. A., Racherla, P., and Bush, V. D. (2014). "What we know and don't know about online word-of-mouth: A review and synthesis of the literature," Journal of Interactive Marketing, 28(3), pp. 167-183.

Ko, D. G., Kirsch, L. J., and King, W. R. (2005). "Antecedents of knowledge transfer from consultants to clients in enterprise system implementations," MIS quarterly, 29(1), pp. 59-85.

Koufaris, M. (2002). "Applying the technology acceptance model and flow theory to online consumer behavior," Information systems research, 13(2), pp. 205-223.

Llamero, L. (2014). "Conceptual mindsets and heuristics in credibility evaluation of e-Word of Mouth in tourism," Online Information Review, 38(7), pp. 954968.

Liu, Y. (2006). "Word of mouth for movies: Its dynamics and impact on box office revenue," Journal of marketing, 70(3), pp. 74-89.

McKinney, V., Yoon, K., and Zahedi, F. M. (2002). "The measurement of webcustomer satisfaction: An expectation and disconfirmation approach," Information systems research, 13(3), pp. 296-315.

Moon, J. W., and Kim, Y. G. (2001). "Extending the TAM for a World-WideWeb context," Information and management, 38(4), pp. 217-230.

Mudambi, S. M., and Schuff, D. (2010). "What makes a helpful review? A study of customer reviews on Amazon.com," MIS quarterly, 34(1), pp. 185-200.

Negash, S., Ryan, T., and Igbaria, M. (2003). "Quality and effectiveness in web-based customer support systems," Information and Management, 40(8), pp. 757-768.

Park, C., and Lee, T. M. (2009). "Antecedents of online reviews' usage and purchase influence: An empirical comparison of US and Korean consumers," Journal of Interactive Marketing, 23(4), pp. 332-340.

Pavlou, P. A. (2003). "Consumer acceptance of electronic commerce: 
Integrating trust and risk with the technology acceptance model," International journal of electronic commerce, 7(3), pp. 101134.

Petty, R. E., and Cacioppo, J. T. (1986). The elaboration likelihood model of persuasion. In Communication and persuasion (pp. 1-24). Springer New York.

Ping, R. A. (2004). "On assuring valid measures for theoretical models using survey data," Journal of Business Research, 57(2), pp. 125-141.

Pitta, D. A., and Fowler, D. (2005). "Internet community forums: an untapped resource for consumer marketers," Journal of Consumer Marketing, 22(5), pp. 265-274.

PwC (2016), "They say they want a revolution Total Retail 2016," retrieved from http://www.pwc.com/gx/en/retailconsumer/publications/assets/totalretail-global-report.pdf.

Podsakoff, P. M., MacKenzie, S. B., Lee, J. Y., and Podsakoff, N. P. (2003). "Common method biases in behavioral research: a critical review of the literature and recommended remedies," Journal of applied psychology, 88(5), pp. 879-903.

Podsakoff, P. M., and Organ, D. W. (1986). "Self-reports in organizational research: Problems and prospects," Journal management, 12(4), pp. 531-544.

PTI (2016), Press Trust of India. 2016. India's e-commerce industry likely to touch $\$ 38$ billion mark in 2016 Assocham. Retrieved from https://yourstory.com/2016/01/indiase-commerce-assocham/.

Ryu, K., Han, H., and Kim, T. H. (2008). "The relationships among overall quick-casual restaurant image, perceived value, customer satisfaction, and intentions," International Journal of Hospitality Management, 27(3), pp. 459-469.

Schmallegger, D., and Carson, D. (2008). "Blogs in tourism: Changing approaches to information exchange," Journal of vacation marketing, 14(2), pp. 99-110.

Scherer, A., Wünderlich, N., and von Wangenheim, F. (2015). "The Value of Self-Service: Long-Term Effects of Technology-Based Self-Service Usage on Customer Retention," MIS Quarterly, 39(1), pp. 177-200.

Shen, X.L., Wang, N., Sun, Y., and Xiang, L. (2013). "Unleash the power of mobile word-of-mouth: An empirical study of system and information characteristics in ubiquitous decision making," Online Information Review, 37(1), pp.42-60.

Sher, P. J., and Lee, S. H. (2009). "Consumer skepticism and online reviews: An elaboration likelihood model perspective," Social Behavior and Personality: an international journal, 37(1), pp. 137-143.

Sirdeshmukh, D., Singh, J., and Sabol, B. (2002). "Consumer trust, value, and loyalty in relational exchanges," Journal marketing, 66(1), pp.15-37.

Song, J., Kim, J., Jones, D. R., Baker, J., and Chin, W. W. (2014). "Application discoverability and user satisfaction in mobile application stores: An environmental psychology perspective," Decision Support Systems, 59, pp. 37-51.

Sussman, S. W., and Siegal, W. S. (2003). "Informational influence in organizations: An integrated approach to knowledge adoption," Information systems research, 14(1), pp. 47-65.

Stauss, B. (1997). "Global word of mouth: service bashing on the Internet is a thorny issue," Marketing Management, 6(3), pp. 28-30. 
Tam, K. Y., and Ho, S. Y. (2005). "Web personalization as a persuasion strategy: An elaboration likelihood model perspective," Information Systems Research, 16(3), pp. 271291.

Todorov, A., Chaiken, S., and Henderson, M. D. (2002). "The heuristicsystematic model of social information processing," The persuasion handbook: Developments in theory and practice, pp. 195-211.

Wang, R. Y., and Strong, D. M. (1996). "Beyond accuracy: What data quality means to data consumers," Journal of management information systems, 12(4), pp. 5-33.

Wathen, C. N., and Burkell, J. (2002). "Believe it or not: Factors influencing credibility on the Web," Journal of the American society for information science and technology, 53(2), pp. 134-144.

Wu, C., and Shaffer, D. R. (1987). "Susceptibility to persuasive appeals as a function of source credibility and prior experience with the attitude object," Journal of personality and social psychology, 52(4), pp. 677-688.

Xie, K. L., Chen, C., and Wu, S. (2016). "Online consumer review factors affecting offline hotel popularity: evidence from tripadvisor," Journal of Travel and Tourism Marketing, 33(2), pp. 211-223.
$\mathrm{Xu}, \mathrm{X}$., and Yao, Z. (2015). "Understanding the role of argument quality in the adoption of online reviews: An empirical study integrating valuebased decision and needs theory," Online Information Review, 39(7), pp. 885-902.

Zeithaml, V. A. (1988). "Consumer perceptions of price, quality, and value: a means-end model and synthesis of evidence," The Journal of marketing, 52(3), pp. 2-22.

Zhang, K. Z., Zhao, S. J., Cheung, C. M., and Lee, M. K. (2014). "Examining the influence of online reviews on consumers' decision-making: A heuristic-systematic model," Decision Support Systems, 67, pp. 78-89.

Zhang, W., and Watts, S. A. (2008). "Capitalizing on content: Information adoption in two online communities," Journal of the Association for Information Systems, 9(2), pp. 73-94.

Zhou, W., and Duan, W. (2016). "Do Professional Reviews Affect Online User Choices through User Reviews?: An Empirical Study," Journal of Management Information Systems, 33(1), pp. 202-228.

Zhu, F., and Zhang, X. (2010). "Impact of online consumer reviews on sales: The moderating role of product and consumer characteristics," Journal of marketing, 74(2), pp. 133-148. 


\section{Appendix}

\begin{tabular}{|l|l|c|c|}
\hline Annexure 1 - Demographic Summary of Respondents \\
\hline Group & Category & Count & Percentage \\
\hline \multirow{2}{*}{ Gender of the Respondent } & Male & 209 & 65.3 \\
\cline { 2 - 4 } & Female & 111 & 34.7 \\
\hline \multirow{3}{*}{ Age group of the Respondent } & Below 21 yrs. & 1 & 0.3 \\
\cline { 2 - 4 } & $21-30 y r s$ & 310 & 96.9 \\
\cline { 2 - 4 } & Above 30 yrs. & 9 & 2.8 \\
\hline \multirow{3}{*}{ Qualification of the Respondent } & Graduation & 81 & 25.3 \\
\cline { 2 - 4 } & Post-Graduation and above & 228 & 71.3 \\
\cline { 2 - 4 } & Professional Qualification & 11 & 3.4 \\
\hline \multirow{4}{*}{ Monthly Income of the Family (INR* } & Less than 50,000 & 40 & 12.5 \\
\cline { 2 - 4 } & $50,001-100,000$ & 86 & 26.9 \\
\cline { 2 - 4 } & $100,001-150,000$ & 62 & 19.4 \\
\cline { 2 - 4 } & More than 150,000 & 132 & 41.3 \\
\hline \multirow{3}{*}{$\begin{array}{l}\text { Number of times purchased online in } \\
\text { the last 3 months }\end{array}$} & None & 30 & 9.4 \\
\cline { 2 - 4 } & 1 to 2 times & 93 & 29.1 \\
\cline { 2 - 4 } & 3 to 5 times & 126 & 39.4 \\
\cline { 2 - 4 } & More than 5 times & 71 & 22.1 \\
\hline
\end{tabular}

\section{About the Author}

Mr. T Sai Vijay is presently enrolled as doctoral student, in the area of Marketing, at Indian Institute of Management (IIM) Raipur. His research interest includes - online consumer behaviour, online consumer reviews, consumer buying behavior for new and innovative products, customer relationship marketing and impulse buying behaviour.

Dr. Sanjeev Prashar is a Professor at Indian Institute of Management Raipur India in the area of Marketing Management. Prior to this, he worked with Institute of Management Technology (IMT), Ghaziabad, as Professor in the area of Marketing Management. His areas of interest are Impulse Buying, Online Buying, Mall Selection, Rural Marketing, International Marketing /Exports Management and Marketing of Services. He has published research papers/Case studies in various journals like -Richard Ivey School of Business, Emerald Group Publishing Limited, IGI Publishing Limited, Inderscience Publishers, Palgrave Macmillan and Journal of Retailing and Consumer.

Mr. Chandan Parsad is a FPM student at the Indian Institute of Management Raipur. $\mathrm{He}$ is pursuing his doctorate in the area of Marketing and his research interest include - Retailing, Impulse Buying, Rural marketing and Micromarketing.

Dr. Mukesh Kumar is an Assistant Professor of Communications at IIM Raipur, a leading B-school in India. Professor Kumar has a research interest in mediated communication, public speaking anxiety and crisis communication. Over the years, Prof. Kumar has published many business cases in these areas of communication. 